\title{
Assessment of Microbial Risks in Soil and Bulb Onions (Allium cepa) Grown in the Old Eldoret Municipal Dumpsite, Kenya
}

\author{
Choge Phoebe $^{1}$,Lutta Samwel ${ }^{2}$, Biwott K. Gilbert ${ }^{3}$, Tarus J. Sharon ${ }^{4}$ \\ ${ }^{1,2,4}$ Department of Chemistry and Biochemistry, University of Eldoret, Kenya \\ ${ }^{3}$ Department of Biological Sciences, University of Eldoret, Kenya
}

\begin{abstract}
Urban agriculture plays a very significant role towards improving urban food security, employment creation and in supplementing household income. It is however associated with diverse negative environmental and health impacts. In Eldoret town, Uasin Gishu County, Kenya, the old municipal dumpsite has become an ideal site for growing vegetables and sewage sludge is applied to the vegetables without regards to risks of pathogenic organisms which are precursors to diseases like dysentery, typhoid, tetanus and cholera among others. This research was conducted to determine levels of total coliform, feacal coliform and presence E. coli in soil and bulb onions (Allium cepa) grown in the dumpsite. A total of 18 samples were analysed using multiple tube fermentation technique. Level of total coliform and feacal coliform in the soil were 3,893 and 3,068 MPN/100 ml respectively while in onions the levels were 10,576 and 5,861 MPN/100 ml respectively; these levels are above the recommended standards of WHO. It was therefore concluded that the vegetables are not good for human consumption since they have high levels of feacal coliform and hence pathogenic organisms which are likely to pose health complications.
\end{abstract}

Keywords: Vegetables, Coliform Bacteria, Sewage Sludge and Dumpsite

\section{Introduction}

Farming in urban and peri-urban areas in developing countries is characterized by the use of wastewater which is regarded as a resource of global importance (Bruechler et al., 2002). The use of wastewater helps to circumvent the problem of water scarcity and nutrient deficiency in agricultural farms (Kassan, 2010; McKenzie, 2005). However, occurrence of uncontrolled urban sewage farming like the use of untreated or partially treated wastewater is a common site in African cities. This practice exposes consumers of such produce to poisoning from heavy metals, pathogenic contamination among others (Ebong et al., 2008). The use of untreated sewage wastewater across urban and rural cities in Kenya has also increased with water scarcity and the rising cost of synthetic fertilizers (Kutto et $a l ., 2012)$. When such water is used for irrigation, the food crops absorb appreciable amounts of contaminants which are finally transferred to consumers.

\subsection{Problem Statement}

Huruma is a highly populated region that is occupied by middle and low class people living in an overcrowded area with poor sanitation and inadequate or unsafe water source for domestic use and other activities. In an attempt to cater for basic needs, residents of Huruma especially the low income earners, grow vegetables and grains in the old Eldoret municipal dumpsite because of limited land spaces. These farmers use liquid slurry from the Eldoret sewage to enhance fertility of food crops. The sewage sludge is readily available and apart from providing water to the crops, it is also regarded as a rich source of nutrients like nitrogen. However, the sewage sludge is not good for farming and the food crops irrigated could absorb contaminants. An earlier study conducted by Khazenzi (1996) showed that domestic and industrial sewage waste in Eldoret is not properly treated because the sewage treatment works cannot cope with total sewage discharge. The food crops are also exposed to feacal contamination because residents of Huruma frequently have to rely on unsewered communal toilets or use open space; as a result the feacal wastes are washed to the farming areas and water bodies. In addition, the available sewerage system in the area is very poor; some pipes are broken and therefore effluent find their way to the river and consequently to the vegetable farms. Sewage wastewater contains a significant amount of disease-causing pathogenic organisms (bacteria, virus, protozoa e.t.c) along with other parasitic helminthes which can give rise to health hazards on human beings, animals and plants (Chaurasia and Dwivedi, 2008; Oboubie et al., 2006). On the basis of the above highlights, this study was undertaken to assess the levels of coliform bacteria in soil and bulb onions grown on the dumpsite and subsequently determine the produce's safety for human consumption.

\section{Literature Review}

Lock and De Zeeuw (2003); Blumenthal and Peasey (2002) reported that food grown using sewage wastewater may be contaminated with pathogenic organisms and disease vectors which are responsible for human diseases like helminthiasis, cholera, typhoid, shigellosis, gastric ulcers caused by Helicobacter pylori, giardiasis and amoebiasis. Similarly, report of IWMI (2006) showed that the use of wastewater for vegetable farming is a major source of diarrheal disease; the top cause of death among children in the developing world. These pathogens are transmitted by direct contact with farmers and to the general public through consumption of irrigated produce especially crops eaten raw (Blumenthal et al., 2000).

\section{Volume 6 Issue 12, December 2017}




\section{International Journal of Science and Research (IJSR) \\ ISSN (Online): 2319-7064}

Index Copernicus Value (2016): 79.57 | Impact Factor (2015): 6.391

\section{Experimental}

This study was conducted at the old Eldoret municipal dumpsite. Bulb onion (Allium cepa) which are sometimes consumed raw in vegetable salads and represented major species grown in the old Eldoret municipal dumpsite was used. A total of 27 samples were used in two experimental runs carried out between December 2013 and January 2014. Soil and edible portions of bulb onions were collected randomly from nine identified sites into sterile plastic bags and labeled. The samples were then transported to the laboratory for analysis. At each sample site 3 replicate samples were collected randomly.

Analysis of coliform bacteria in bulb onions and soil samples was done using standard multiple tube fermentation technique according to APHA (2001); Bartram and Pedley (1996) with few modifications. In the presumptive phase, lactose broth was used as a culture media. The media was prepared by suspending $13 \mathrm{~g}$ of lactose broth in $1000 \mathrm{ml}$ distilled water, mixed well then heated to dissolve completely. The media was distributed into universal bottles containing inverted Durham tubes then sterilized by autoclaving at $121{ }^{\circ} \mathrm{C}$ for 15 minutes and allowed to cool. The universal bottles were then arranged in rows of three and each bottle was inoculated in a set of three replicate bottles in increasing sample dilution $\left(10^{1}, 10^{-0}\right.$ and $\left.10^{-1}\right)$. Test portions were mixed with the medium by gentle agitation after which the inoculated bottles were incubated at $35{ }^{\circ} \mathrm{C}$ for $24 \pm 2 \mathrm{hrs}$ then swirled gently to examine for growth, gas and acidic reaction (shades of yellow color). In some universal bottles where no gas production was evident, the bottles were reincubated and reexamined at the end of 48 $\pm 3 \mathrm{hrs}$. The presence or absence of growth, gas and acidic reaction was recorded. Presence of an acidic reaction, growth or gas in the Durham tubes within $48 \pm 3 \mathrm{hrs}$ constituted a positive presumptive test.

Brilliant green lactose bile broth was used as a culture media in confirmed phase. The media was prepared by suspending $40.01 \mathrm{~g}$ of brilliant green lactose bile broth in $1000 \mathrm{ml}$ distilled water and mixed well to dissolve completely. The media was then dispensed into universal bottles containing inverted Durham tubes then sterilized by autoclaving at 121 ${ }^{\circ} \mathrm{C}$ for 15 minutes after which they were allowed to cool. The universal bottles giving positive response in the presumptive phase were shaken gently to re-suspend the organisms after which three loopfuls of culture were transferred using a sterile loop of $3.5 \mathrm{~mm}$ in diameter to universal bottles containing brilliant green lactose bile broth. The inoculated brilliant green lactose bile broth bottles were incubated at $35{ }^{\circ} \mathrm{C}$. Formation of gas of any amount in the inverted Durham tubes of the brilliant green lactose bile broth fermentation bottles at any time within $48 \pm 3 \mathrm{hrs}$ constituted a positive confirmed phase. Most probable number of total coliform was determined from MPN tables (APHA, 2001).

In the elevated-temperature test, $E$. coli broth was used as a culture media. The media was prepared by suspending 37.0 $\mathrm{g}$ of $E$. coli broth in $1000 \mathrm{ml}$ distilled water and mixed well to dissolve. The media was dispensed to universal bottles containing inverted Durham tubes, sterilized by autoclaving at $121{ }^{\circ} \mathrm{C}$ for 15 minutes then allowed to cool. Elevatedtemperature test for distinguishing organisms of the total coliform group that also belong to the feacal coliform group was used. All presumptive fermentation universal bottles showing any amount of gas, growth or acidity within $48 \mathrm{hrs}$ of incubation were shaken gently then subjected to the feacal coliform test. A sterile loop with diameter of $3.5 \mathrm{~mm}$ was used to transfer culture to a universal bottle containing $E$. coli broth after which the inoculated $E$. coli broth was incubated at $44.5{ }^{\circ} \mathrm{C}$ for $24 \pm 2 \mathrm{hrs}$. Gas production with growth in an E. coli broth culture within $24 \pm 2 \mathrm{hrs}$ or less constituted a positive feacal coliform test. Most probable number of feacal coliform was similarly determined from MPN tables (APHA, 2001).

Eosin methylene blue agar was used to determine the presence of $E$. coli. The agar was prepared by suspending $37.46 \mathrm{~g}$ of Eosin methylene blue agar in $1000 \mathrm{ml}$ distilled water and mixed well to dissolve. Culture was transferred from all the positive presumptive tubes that also gave a positive response in feacal test and cultured by streaking on EMB agar plates then incubated at $35{ }^{\circ} \mathrm{C}$ for 24 hours. Positive plates contained typical colonies with green metallic sheen.

\subsection{Data Analysis and Presentation}

All data were analysed using descriptive methods. Statistical analysis was done using SPSS version 20.0.

\section{Results}

\section{Levels of Total Coliform and Feacal Coliform in Onions} and Soil

Table 4.1: Levels of total coliform and feacal coliform in soil

\begin{tabular}{|c|c|c|}
\hline $\begin{array}{c}\text { Samples } \\
\text { site }\end{array}$ & $\begin{array}{l}\text { Total coliform } \\
\text { MPN/100 ml }\end{array}$ & $\begin{array}{c}\text { Feacal coliform } \\
\text { MPN/100 ml }\end{array}$ \\
\hline \multirow[b]{2}{*}{1} & 200 & 200 \\
\hline & 280 & 280 \\
\hline \multirow[b]{2}{*}{2} & 24000 & 11000 \\
\hline & 11000 & 11000 \\
\hline \multirow[b]{2}{*}{3} & 420 & 420 \\
\hline & 440 & 440 \\
\hline \multirow[b]{2}{*}{4} & 530 & 530 \\
\hline & 440 & 440 \\
\hline \multirow[b]{2}{*}{5} & 430 & 430 \\
\hline & 750 & 750 \\
\hline \multirow[b]{2}{*}{6} & 930 & 930 \\
\hline & 1500 & 280 \\
\hline \multirow[b]{2}{*}{7} & 280 & 280 \\
\hline & 350 & 280 \\
\hline \multirow[b]{2}{*}{8} & 930 & 930 \\
\hline & 1500 & 930 \\
\hline \multirow[b]{2}{*}{9} & 24000 & 24000 \\
\hline & 2100 & 2100 \\
\hline
\end{tabular}

\section{Volume 6 Issue 12, December 2017}




\section{International Journal of Science and Research (IJSR) \\ ISSN (Online): 2319-7064}

Index Copernicus Value (2016): 79.57 | Impact Factor (2015): 6.391

Table 4.2: Levels of total coliform and feacal coliform in onions

\begin{tabular}{|c|c|c|}
\hline $\begin{array}{c}\text { Samples } \\
\text { sites }\end{array}$ & $\begin{array}{c}\text { Total coliform } \\
\text { MPN/100 ml }\end{array}$ & $\begin{array}{c}\text { Feacal coliform } \\
\text { MPN/100 ml }\end{array}$ \\
\hline \multirow{3}{*}{1} & 2900 & 11000 \\
\cline { 2 - 3 } 2 & 24000 & 2100 \\
\hline \multirow{3}{*}{3} & 2100 & 2100 \\
\hline \multirow{3}{*}{4} & 1500 & 1500 \\
\cline { 2 - 3 } & 24000 & 24000 \\
\cline { 2 - 3 } & 4600 & 750 \\
\hline \multirow{3}{*}{5} & 11000 & 2100 \\
\cline { 2 - 3 } & 24000 & 2100 \\
\hline & 2900 & 750 \\
\hline
\end{tabular}

\begin{tabular}{|c|c|c|}
\hline \multirow{3}{*}{6} & 2100 & 2100 \\
\cline { 2 - 3 } 7 & 420 & 260 \\
\hline \multirow{3}{*}{8} & 24000 & 24000 \\
\cline { 2 - 3 } & 2900 & 1500 \\
\cline { 2 - 3 } 9 & 24000 & 4600 \\
\hline \multirow{3}{*}{9} & 24000 & 24000 \\
\cline { 2 - 3 } & 4600 & 2100 \\
\hline
\end{tabular}

Levels of total coliform and feacal coliform in soil of onions ranged from 200 to $24,000 \mathrm{MPN} / 100 \mathrm{ml}$. Levels of total coliform in onions ranged from 340 to $24,000 \mathrm{MPN} / 100 \mathrm{ml}$ while feacal coliform ranged from 260- 24,000 MPN/100 $\mathrm{ml}$. The range was slightly higher in onions than in soil.

Table 4.3: Mean of total coliform and feacal coliform in soil

\begin{tabular}{|c|c|c|c|c|c|c|}
\hline & Number of samples & Minimum & Maximum & Mean & Std. Error Mean & Std. Deviation $( \pm)$ \\
\hline Total coliform in soil & 18 & 200.00 & 24000.00 & 3893.00 & 1819.20 & 7718.22 \\
\hline Feacal coliform in soil & 18 & 200.00 & 24000.00 & 3067.00 & 1465.89 & 6219.27 \\
\hline
\end{tabular}

Average total coliform in soil was 3,893 MPN/100 ml while feacal coliform in soil was 3,068 MPN/100 ml. The average value of feacal coliform in soil was significantly higher than acceptable standard of <1000 MPN/100 ml (WHO, 2006).

Table 4.4: Mean of total coliform and feacal coliform in onion

\begin{tabular}{|c|c|c|c|c|c|c|}
\hline & Number of samples & Minimum & Maximum & Mean & Std. Error Mean & Std. Deviation $( \pm)$ \\
\hline Feacal coliform & 18 & 200.00 & 24000.00 & 5861.00 & 2048.53 & 8691.18 \\
\hline Total coliform & 18 & 340.00 & 24000.00 & 10576.00 & 2400.81 & 10185.77 \\
\hline
\end{tabular}

The average number of total coliform in onion was 10576 MPN/100 ml while that of feacal coliform was 5,861 MPN/100 ml. The average value of feacal coliform in onions was considerably high than the acceptable limit of $<200$ MPN/100 ml (WHO, 2006) and standard of 0 MPN/100 ml set by USEPA/USAID (1992).

The bulb onions and soil was subjected to complete test of multiple tube fermentation technique to determine whether they were contaminated with $E$. coli strains. The results indicated that soil and onions from all the nine sample sites were contaminated with E. coli strains. Sample plates showing positive response in complete test are provided in the figure below.

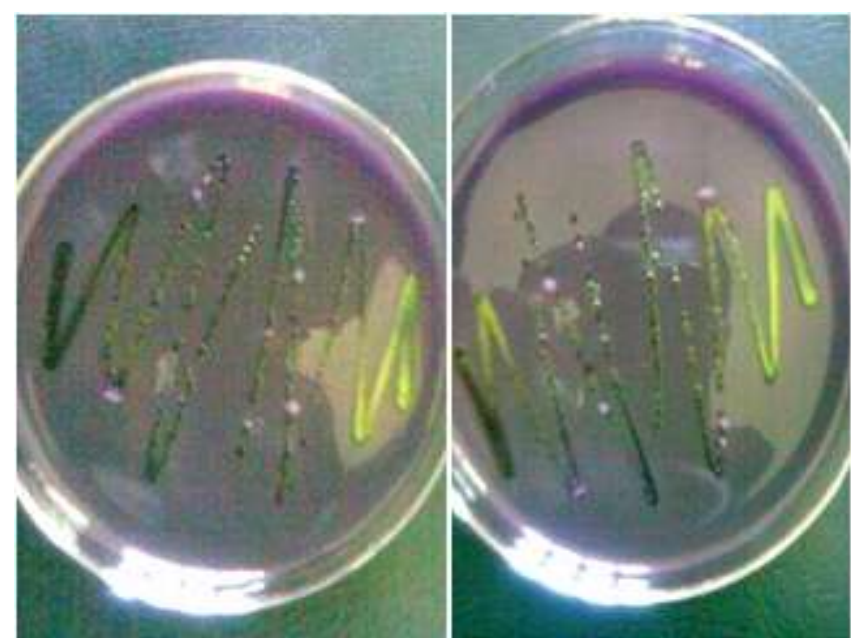

Figure 1: Plates showing positive response in complete test; the green metallic sheen are typical colonies of E. coli strains

\section{Discussion}

Soil and bulb onions obtained from the old Eldoret municipal dumpsite were analysed to determine levels of coliform bacteria. Coliform bacteria are known to be indicators of pathogenic organisms which are precursors to different diseases. Due to their known harmful effects to plants, animals and human beings, critical levels of coliform bacteria have been established by several authorities. The results obtained in this study on level of coliform bacteria were compared with acceptable standard of WHO (2006). The edible portions of bulb onions were used in the research because edible portions come in direct contact with human beings during consumption.

Average value of total coliform in soil was 3,893 MPN/100 $\mathrm{ml}$ while feacal coliform was 3,068 MPN/100 ml. The average count of feacal coliform in soil samples $(3,068$ MPN/100 ml) was higher than the accepted level of $<1,000$ MPN/100 $\mathrm{ml}$ as per WHO (2006) requirement. Thus, the soil of the old Eldoret municipal dumpsite may harbor higher levels of feacal coliform to food crops and should not be used for growing crops. Average total coliform in onion was $10576 \mathrm{MPN} / 100 \mathrm{ml}$ while feacal coliform in onion was 5,861 MPN/100 ml. The level of feacal coliform in onions $(5,861 \mathrm{MPN} / 100 \mathrm{ml})$ were also significantly higher than the accepted level of (<200 MPN/100 ml) as per WHO (2006). This was also higher compared to acceptable standard of 0 MPN/100 $\mathrm{ml}$ set by USEPA/USAID (1992). Therefore the onions were not safe for human consumption as far as level of feacal coliform is concerned.

The high counts recorded for the total coliform and feacal coliform reflect the presence of human excreta at the waste dumpsite. This unsanitary activity is common in such a congested region like Huruma estate where adequate sewage

\section{Volume 6 Issue 12, December 2017}

\section{www.iisr.net}

Licensed Under Creative Commons Attribution CC BY 


\section{International Journal of Science and Research (IJSR) \\ ISSN (Online): 2319-7064}

Index Copernicus Value (2016): 79.57 | Impact Factor (2015): 6.391

systems are lacking. This can also be attributed to: the poor sewage system in the area which allows effluent to flow to the vegetable farm, direct application of raw sewage sludge to the vegetables and the fact that some residents defecate in the vegetable farms. The higher level can also be attributed to the fact that onions grow underground. The extent of microbial contamination decreases if the vegetable's edible parts are above the ground while it increases if they are near the ground surface (Kwashie, 2009).

Comparison of levels of total coliform and feacal coliform in soil and onions showed that levels of total coliform and feacal coliform were higher in onions than in the soil. The coliform bacteria may have originated from the soil and applied sewage sludge but found a favourable environment in plant tissues. Plant tissues are known to protect pathogens from various disinfection treatments, UV light and provide ample amount of nutrients (Heaton and Jones, 2008). Therefore the micro organisms occupy the plant tissues which offer good environment. Moreover, the coliform bacteria can get into the plant tissues through other paths aside from roots. According to Beuchat (1996b) vegetables or plants can be exposed to pathogenic contamination through various routes which include soil, feaces, sewage, insects, animals and human beings. These routes of exposure to pathogenic contaminations are available in the old Eldoret municipal dumpsite and this explains why the number of coliform bacteria was higher in bulb onions than in soil.

\section{Conclusion}

Results from this study reveal that plants grown on dumpsite soil and irrigated using raw sewage sludge can accumulate pathogenic organisms to high levels. The soil and bulb onions grown in old Eldoret municipal dumpsite were contaminated with total coliform, feacal coliform and E. coli strains. Levels of feacal coliform in soil and vegetables were higher than recommended standard of WHO (2006). This poses health risks to farmers who have a direct contact with the onions and soil and to unsuspecting consumers of the onions especially those who consume them raw. Thus, efforts should be intensified to discourage the practice of growing onions at the dumpsite.

\section{Acknowledgement}

Special thanks to the National Commission of Science, Technology and Innovation (NACOSTI) of Kenya for providing the greatly needed financial support.

It is my pleasure to thank: Prof. Samwel Lutta, Micah Kipchirchir and Biwott Gilbert for the assistance accorded to ensure that my research was a success.

\section{References}

[1] American Public Health Association (APHA). (2001). Standard Methods for Examination of Water and Wastewater. $22^{\text {nd }}$ Edn., APHA-AWWA-WEF, Washington D.C.

[2] Bartram, J. and Pedley, S. (1996). Microbiological Analyses, Water Quality Monitoring - A Practical
Guide to the Design and Implementation of Freshwater Quality Studies and Monitoring Programmes.

[3] Beuchat, L.R. (1996b). Pathogenic microorganisms associated with fresh produce. J. Food Prot., 59:204216.

[4] Blumenthal, U. and Peasey, A. (2002). Critical Review of Epidemiological Evidence of the Health Effects of Wastewater and Excreta Use in agriculture. Unpublished document prepared for WHO (available upon request), Geneva.

[5] Blumenthal, U.J., Peasey, A., Ruiz-Palacios, G. and Mara, D. (2000). Guidelines for wastewater reuse in agriculture and aquaculture: Recommended revisions based on new research evidence. WELL Study, Task No. 68, Part 1. Water and Environmental Health at London and Loughborough (WELL), London, UK.

[6] Bruechler, S., Hertog, W. and Van Veen Huizen, R. (2002). Wastewater Use for Urban Agriculture. Agriculture Magazine. Number 8. pp 3-4.

[7] Chaurasia, S. and Dwivedi, R. (2008). Sewage farming. IJEP. 12: 1089-1092.

[8] Ebong, G.A., Akpan, M.M. and Mkpenie, V.N. (2008). Heavy metal contents of municipal and rural dumpsite soils and rate of accumulation by Carica papaya and Talinum triangulare in Uyo, Nigeria. E-Journal of Chemistry http://www.e-journals.net, 5: 281-290.

[9] Heaton, J.C. and Jones, K. (2008). Microbial contamination of fruit and vegetables and the behaviour of enteropathogens in the phyllosphere: a review. Journal of Applied Microbiology. vol 104 (3):613-626.

[10] IWMI. (2006). Recycling realities: managing health risks to make waste water reuse an asset. Water policy briefing, issue 17.

[11] Kassan, H. (2010). Waste water reuse in Africa. Presentation made at a conference. SIWW, 2010.

[12] Khazenzi, J.A. (1996). Sewage and solid medical waste pollution loads in Eldoret municipality. M. Ph in Environmental Studies; Moi University.

[13] Kutto, E.K., Mwangi, M.W., Karanja, N., Kang'ethe, E., Bebora, L.C., Lagerkvist, C.J., Mbuthia, P.G., Njagi, L.W. and Okello, J.J. (2012). Bacterial contamination of kale (brassica oleracea acephala) along the supply chain, in Nairobi and its environs.

[14] Kwashie, K.C. (2009). Microbial analysis of soil samples in a wastewater irrigated vegetable production site: case study at Atonsu, Kumasi.

[15] Lock, K. and De Zeeuw, H. (2003). Health and Environmental risks associated with urban agriculture. Paper presented at a workshop on health risks and benefits in urban agriculture and livestock farming in sub Saharan Africa. Nairobi, Kenya, June 9-12, 2003.

[16] McKenzie, C. (2005). Wastewater reuse conserves water and protects water ways. On tap winter 2005, pp 46-51.

[17] Obuobie, E., Keraita, B., Danso, G., Amoah, P., Cofie, O.O., Rachid-Sally, L. and Drechsel, P. (2006). Irrigated Urban Vegetable Production in Ghana. Characteristics, Benefits and Risks. CSIR-INST Accra, Ghana. Pp.70-98.

[18] USEPA/USAID (United States Environmental Protection Agency/United States Agency for International Development). (1992). Guidelines for 


\section{International Journal of Science and Research (IJSR) \\ ISSN (Online): 2319-7064}

Index Copernicus Value (2016): 79.57 | Impact Factor (2015): 6.391

Water Reuse United States Environmental Protection Agency. (Technical Report no. 81), Washington, DC, $252 \mathrm{pp}$.

[19] World Health Organisation. (2006). Guidelines for Safe use of Wastewater, Excreta and Grey Water: Policy and Regulatory Aspects, vol 1-4.

\section{Author Profile}

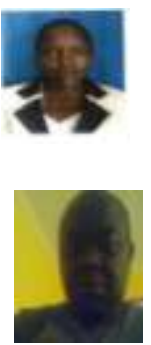

Choge Phoebe, MSc. Student at University of Eldoret; Department of Chemistry and Biochemistry, University of Eldoret, Kenya.

Prof. Lutta Samwel, Chemistry lecturer at University of Eldoret; Department of Chemistry and Biochemistry, University of Eldoret, Kenya.

Tarus J. Sharon, MSc. Student at University of Eldoret ; Department of Chemistry and Biochemistry, University of Eldoret, Kenya. 